Egyptian Journal of Aquatic Biology \& Fisheries

Zoology Department, Faculty of Science,

Ain Shams University, Cairo, Egypt.

ISSN $1110-6131$

Vol. 25(3): 39 - 61 (2021)

www.ejabf.journals.ekb.eg

\title{
Comparative taxonomical studies on the Egyptian Mediterranean octopuses (Octopoda: Cephalopoda)
}

\author{
Rafik Riad \\ National Institute of Oceanography and Fisheries, Alexandria, Egypt. \\ Rafik_riad67@yahoo.com
}

\begin{abstract}
Article History:
Keywords:

Comparative,

Octopuses

Egyptian,

Mediterranean,

Octopoda,

Cephalopoda.
\end{abstract}

ARTICLE INFO

Received: March 26, 2021

Accepted: May 16, 2021

Online: May 24, 2021

\section{ABSTRACT}

Octopuses have gained a considerable worldwide commercial importance. Hence, this study was conducted to differentiate between the Octopoda species in the Egyptian Mediterranean waters. The study extended from January 2019 to December of the same year. Octopus specimens were seasonally obtained from the fishing trawlers operating in the Egyptian Mediterranean waters from Sidi Abd El-Rahman, west of Alexandria to Rosetta in the east. The different organs were illustrated using a zoom stereoscopic WildM8 microscope provided with a special camera Lucida drawing tube, and photographed by a Canon G7Xdigital camera.

Four Egyptian Mediterranean octopus species were detected, among which Eledone moschata, Octopus vulgaris, Callistoctopus macropus, and Macrotritopus defilippii were identified. Whereas three of them: Octopus vulgaris, Callistoctopus macropus, and Macrotritopus defilippi are classified as cosmopolitan species in distribution. Considerably, the species Eledone moschata are widely distributed in the Mediterranean Sea.

\section{INTRODUCTION}

Order Octopoda includes two suborders, eleven families, about forty genera, and approximately two hundred species (Nesis, 1987). Generally, from the total catch of world cephalopod fishery, about $14.6 \%$ were octopuses, $13.6 \%$ cuttlefish, and $71.8 \%$ squids (Roper et al., 1984). For the Egyptian Mediterranean fisheries, according to the data of Anon $(1987, \mathbf{1 9 9 8})$, octopuses represent an average of $2.12 \%$ of fish landings. From a systematic point of view, octopod cephalopods are poorly resolved. The family Octopodidae, particularly the genus Octopus, is highly specious and taxonomically difficult (Hochberg et al., 1992), due to the dearth of hard parts or other reliable morphological characters and the high variability of their morphometric. The classification relies largely on the reproductive characteristics of mature males, making females and juveniles difficult to identify, particularly in their preserved state. This poor resolution is reflected in contribution on local cephalopod fauna (Massy, 1928; Robson, 1930; Voss, 1967; Roeleveld, 1975) and new species are still described (Villanueva et al., 1992). Remarkably, morphometric studies could help many in identifying species. 
Clarke (1962) devised a key to families within the octopods using only the beaks. Since then, two other keys have been published in which the beaks were used to identify octopods to families and in some cases to the species level (Akimushkin, 1963; Mangold \& Fioroni, 1966). Nowadays, it is possible to identify species from the characteristic feature of beaks in addition to more precise information about their growth concerning body weight. Within the last few years, some techniques have been developed which represent major advances in the ability of the investigator to discriminate variation in the proteins of many species of organisms. These are of potential benefit to physical anthropologists interested in the biochemical variation in human and non-human primates. Most worthy among these new methods are double internal standard disc electrophoresis pioneered by Johnson N.D, and isoelectric focusing. The latter technique, however, has not been exploited as a research tool for survey studies. The ability of this method to distinguish differences in free electric mobility among other-wise indistinguishable protein molecules would have ordinarily been adopted by many laboratories, except for practical and fiscal considerations which put this powerful tool out of the reach of modesty funded projects (Byles et al., 1979). Twenty-nine cephalopod species are known to occur in the Mediterranean Sea and of these; twenty-four species are known to extend to the Eastern Mediterranean basin, of which eight are Octopoda species (Roper et al., 1984). In the Egyptian waters, from the total catch of world cephalopod fishery, about $14.6 \%$ were octopuses (Roper et al., 1984). In the Mediterranean waters Riad (1993) recorded nine cephalopod species off Alexandria Mediterranean waters, three of them were octopuses. The octopus species recorded were Octopus vulgaris, Callistoctopus macropus, and Eledone moschata. Generally, octopuses, the subject of the present work, are found throughout the world's tropical and temperate ocean (Robson, 1929). It is worth mentioning that Riad et al. (1997) studied the development of Octopus vulgaris from Alexandria Mediterranean waters. Moreover, Saad and Emam (1998) studied the poisonous salivary glands of Octopus vulgaris from the Mediterranean Sea. Additionally, Riad (2000a) studied the biology and the morphometry of three Octopoda species; namely, Octopus vulgaris, Octopuss macropus and Eledone moschata from the Alexandria Mediterranean waters. The previous author used the isoelectric focusing technique to identify the three Octopoda species. Furthermore, Riad (2000b) recorded one first recorded Octopoda species Octopus defilippi from Alexandria Mediterranean waters. On the other hand, Nessim and Riad (2003) studied the bioaccumulation of heavy metals in Octopus vulgaris from Alexandria Mediterranean waters. While Ibrahim et al. (2006) studied the molecular phylogeny of three octopodid species from the Mediterranean waters. Riad and Gabr (2007) conducted a comparative study on Octopus vulgaris from the Mediterranean and Red Sea of Egypt. Moreover, Emam et al. (2008) studied the macro and microscopic structure of the digestive system of Octopus vulgaris from Alexandria Mediterranean waters. It is worthy to mention also that, Riad and Kilada (2012) studied 
the reproductive biology of Eledone moschata from the Alexandria Mediterranean waters.

It should be noted that, according to Jereb et al. (2014), the genus of two octopus species in the present study namely: Octopus macropus and Octopus defilippi have been changed into Callistoctopus macropus and Macrotritopus defilippi, respectively.

\section{MATERIALS AND METHODS}

The octopus specimens of this study were seasonally obtained from commercial fishing trawlers operating in the Egyptian Mediterranean waters during the period from January to December 2019 from Sidi Abd El-Rahman, west of Alexandria to Rosetta in the east (Figure 1). The samples were preserved in a 5\% formalin seawater solution.

According to Roper $\boldsymbol{e t}$ al. (1984), the following characters were carefully examined to identify the specimens to the species level; the hectocotylized arm, radula, gill, beaks, funnel (siphon), and egg cluster. The different organs were illustrated using a zoom stereoscopic WildM8 microscope provided with its special camera Lucida drawing tube, and photographed by a Canon G7Xdigital camera.

This work was organized to evaluate the status of the existing octopus species inhabiting the Egyptian Mediterranean waters to attain a reliable differentiation among those species.

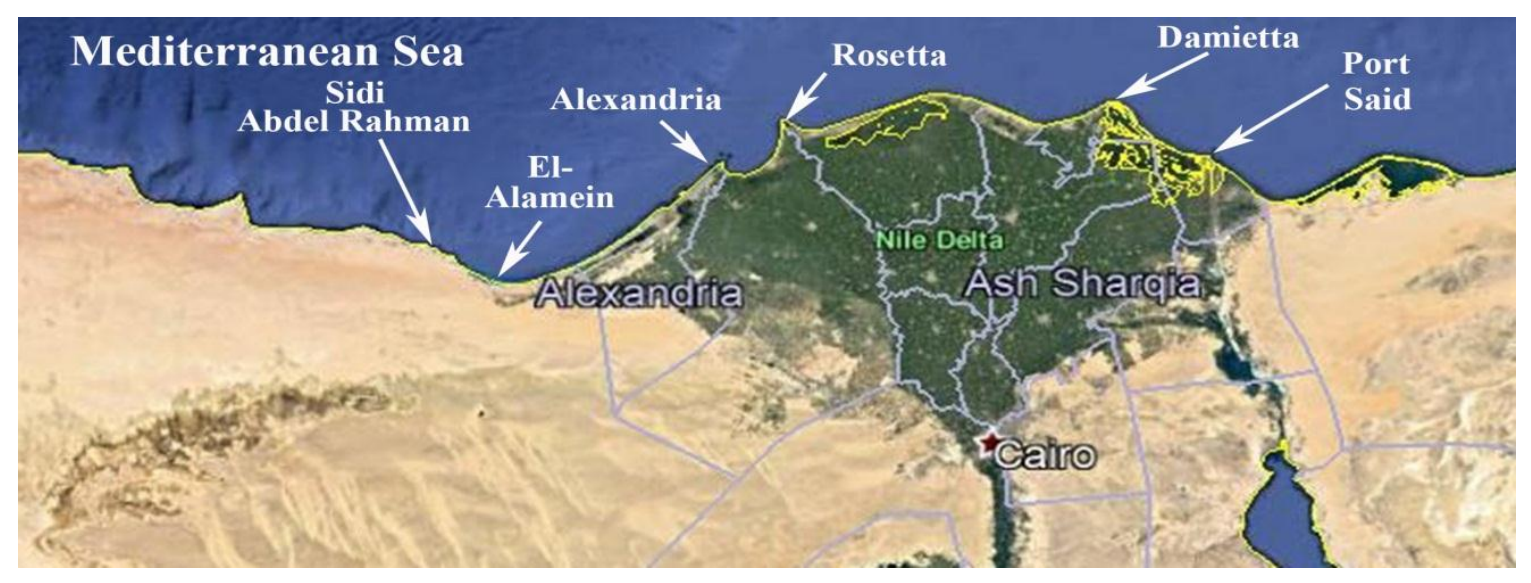

Fig. (1)Egyptian Mediterranean Sea(Google Earth): showing the Egyptian Coast of the Mediterranean from which the samples were collected (from Sidi Abd ElRahman, west of Alexandria to Rosetta in the east . 


\section{RESULTS AND DISCUSSION}

The following four octopus species namely: Eledone moschata, Octopus vulgaris, Callistoctopus macropus, and Macrotritopus defilippi were encountered during the present study three of them: Octopus vulgaris, Callistocopus macropus and Macrotritopus defilippi are cosmopolitan species in distribution. On the other hand, the species Eledone moschata are widely distributed in the Mediterranean Sea.

The taxonomical order of the recorded species is as follows:

\section{Phylum: Mollusca}

Class: Cephalopoda (Cuvier, 1798).

Subclass: Coleoidea (Bather, 1888).

Order: Octopoda (Leach, 1818).

Suborder: Incirrata (Grimpe, 1916).

Family: Octopodidae (d'Orbigny, 1845).

Subfamily: Eledoninae (Gray, 1849).

Genus Eledone (Leach, 1817).

Eledone moschata (Lamarck, 1798).

Subfamily: Octopodinae

Genus Octopus (Lamarck, 1798).

1- Octopus vulgaris (Cuvier, 1797).

Genus: Callistoctopus(Taki,1964).

Callistoctopus macropus (Risso, 1826).

Genus: Macrotritopus(Grimpe,1922).

Macrotritopus defilippi (Verany, 1851).

Key to the recorded genera of the order Octopoda in the present study.

1-Body oval; head furnished with eight nearly equal arms, provided with sessile suckers in a single row on their inner sides. Ink sac presents

(Roper et al., 1984). Eledone

This genus is represented by one species in the present work:

Eledone moschata (Lamarch, 1798).

2- The hectocotylized arm is the third right one. Body firm is more or less muscular. Funnel organ is W or VV shaped. Mantle aperture is not narrow or slightly narrow. Hectocotylus is well developed, with more or less long differentiated ligula and calamus. Mantle aperture is wide. No bright color rings are scattered over body and arms, no ocellar spots on mantle, only round ocellar spots may be present on the web in front of the eyes as well as different stripes, spots patterns, etc., rarely coloration uniform

(Roper et al., 1984).

.Octopus

This genus is represented in the present study by one species, Octopus vulgaris, 
3-Water pouches and pores absent; ligula and calamus well-developed in mature males (shallow-water tropical and temperate species worldwide.. (Roper et al., 1984) Callistoctopus.

This genus is represented in the present study by one species, Callistoctopus macropus.

4-Gills with 11 lamellae per demibranch (shallow-water species of Atlantic Ocean and potentially tropical Indo-West Pacific (Roper et al.,

1984) Macrotritopus

This genus is represented in the present study by one species, Macrotitopus defilippi.

Key to the recorded species in the present study.

1-The eight arms are equal, provided with uniserial suckers, over each eye single cirrus is observed, and a blackish-brown blotch on the dorsal side of the smooth skin is observed

Eledone moschata.

1-Three cirri over each eye, arms are seemingly equal in length; the modified part of arm III of male hectocotylized is very small and spoon-shaped, 11-gill lamellae per each gill. Octopus vulgaris.

2-The dorsal body is ornamented with white spots, the arms are very long, right arm III of male hectocotylized with a large tubular ligula, extending to about $13-15 \%$ of its length, no cirri over eyes, 12-gill lamellae per each

..Callistoctopus macropus.

3-Funnel elongate tube, third arms are very much longer than the other arms, right arm III of male hectocotylized is shorter than the opposite arm. Macrotritopus defilippi.

Four octopus species were recorded in the Egyptian Mediterranean waters namely: Eledone moschata, Octopus vulgaris, Callistoctopus macropus, and Macrotritopus defilippi.

1-Eledone moschata (Lamarck, 1798):

Synonymy: Octopus moschata (Lamarck, 1798); Paulpe musque (Montfort, 1802): Sepia moschata (Bose, 1802); Ozocna moschata (Rafinesque, 1814) (Roper et al., 1984).

World distribution: West Mediterranean Sea, including Adriatic Sea (Roper et al., 1984) East Atlantic Ocean (Roper et al., 1984) and Namibia, ( Luderitz Bay) CapeTown, Littoral and upper sub-littoral environments (Nesis, 1987).

Local name: Okhtaboot, Sabaa dule (Riad, 1993).

Local distribution: The species is recorded off Alexandria shore from Abu Qir Bay (5070 m. depth), El-Agamy (25-54 m. depth), Sidi-Abdel Rahman, (40-80 m. depth), ElMontazah (50 m. depth), Sidi Kreer (40-50 m. depth), and El-Max (40 m. depth), Keyed 
Bay (40 m. depth) and is common in Alexandria fish markets (Anfushy, Abu Qir, Maadeia and Rosetta) (Riad, 1993).

Habitat: Found on muddy sandy gravelly bottoms and also dwells in cavities. Depth ranges from 10 to 300 m (Robson, 1912; Roper et al., 1984).

2-Octopus vulgaris (Cuvier, 1797):

Synonymy: Sepia rugosa (Bosc, 1792); Octopus granulatus (Lamarck, 1798); Octopus vulgaris (Lamarck, 1798); Octopus cassiopeia (Gray, 1849); Octopus tuberculatus (Risso, 1862); Octopus trascheli Targioni (Tozzetti, 1869); Octopus rugosus (Robson, 1929) (Roper et al., 1984).

World distribution: West Mediterranean Sea, including Adriatic Sea (Roper $\boldsymbol{e t}$ al., 1984), Turkish waters (Catagan \& Kocatas, 1990), East Atlantic (Roper et al 1984). In the Atlantic; from Long Island to southern Brazil, and from Southern North Sea to the Cape of Good Hope, common in the Gulf of Mexico and the Caribbean Sea (Nesis, 1987).

Local name: Okhtaboot, Folby and Sabaa deule (Riad, 1993).

Local distribution: The specimens were collected offshore from Alexandria waters, Abu Qir Bay (50-70 m. depth), El-Agamy (25-45 m. depth), Elhamra at Sidi Abd- Alrahman (40-80 m. depth), off El-Montazah (50 m. depth), Sidi Kreer. (40-50 m. depth), EL-Max (40 m. depth), and Kayet Bay (40 m.depth). It is common in Alexandria fish markets (Anfushy, Abu Qir, Maadeia, and Rosetta) (Riad, 1993).

Habitat: On muddy sandy gravelly bottoms and also dwells in cavities. Depth ranges from 10 to 300 m (Robson, 1932; Roper et al., 1984).

3-Callistoctopus macropus (Risso, 1826).

Synonymy: Octopus macropodus (San Giovanni, 1829). Octopus cuvieri (d'Orbigny, 1840); Octopus longimanus (d'Orbigny, 1840); Octopus alderi (Verany, 1851).; Octopus bernudensis (Hoyle, 1885); and Octopus chromatus (Heilprins, 1888).

World distribution: Worldwide in warm waters (Roper et al., 1984).Western and Eastern Mediterranean (Fischer, 1973). Adriatic Sea (Riedle, 1970). North Atlantic, Indian Ocean, Central and Western Pacific Ocean, Gulf of Aqaba (Adam, 1960).North African coast (Fischer, 1973).Tropical Atlantic, Indo-West Pacific species, in the western Atlantic mainly near Bermuda and Bahamas Islands, Southern Florida to Brazil, Caribbean Sea, western Africa to the Gulf of Guinea, Ascension and Santa Helena Islands (Nesis, 1987).

Local name: Okhtaboot, Sabaa deule and Hebal (Riad, 1993).

Local distribution: The species was collected offshore from Abu Qir Bay (50-70 m depth), El-Agamy (25-45 m depth), Sidi-Abd- Alrahman (40-80 m depth), off ElMontazah (50 m depth), Sidi -Kreer (40- 50 m depth), El-Max (40 m depth), off Kait Bye 
(35 m depth) It is common in Alexandria fish markets (Anfushy, Abu Qir, Maadeia and Rosetta) (Riad, 1993).

Habitat: The species lives on rocky bottoms, in crevices and holes, sometimes found on vegetated substrates (Fischer, 1973). A benthic shallow-water species occurring in coral reefs, reef flats, and on open bottoms (Roper et al., 1984). In the present study, the species was captured from muddy sandy grounds at Abu Qir Bay.

4-Macrotritopus defilippi (Verany, 1851).

Synonymy: Macrotritopus species (Roper et al., 1984).

World distribution: the Mediterranean Sea, Eastern Atlantic from Morocco to Angola, Cape Verde Islands, Western Atlantic, Bahamas, Gulf of Mexico, Caribbean Sea, Brazil, Indian Ocean, Arabian Peninsula to Burma and South Western Pacific (Roper, et al., 1984; Nesis, 1987; Mangold, 1998).

Local name: Okhtaboot and Sabaa deule (Riad, 1993).

Local distribution: The species was detected in Sidi Abdel Rahman locality and commercial fish trawl from Alexandria Mediterranean waters. It is common in Alexandria fish markets (Riad, 1993).

Habitat: Inhabits biolistic bottom at a depth of 30-60 m. According to Roper $\boldsymbol{e t}$ al. (1984), the species is little known as benthic species inhabiting sandy to muddy bottoms at a water column depth of 6 to $60 \mathrm{~m}$, but occasionally reported down to 200 m.(acrotritopus larva). Its larvae and juveniles are pelagic (Roper et al., 1984).

\section{Description:}

The specimens in hand are in good agreement with the descriptions given by the aforementioned previous authors.

I-External morphological features :( PLATE 1).

1-Eledone moschata: The mantle is ovoid, more or less broad, and rounded posteriorly. The head is narrower than the mantle. The eight arms are equal, provided with uniserial suckers, the arms are united at their bases by a strong web, which connects them for some distance, about $33 \%$ of the total arm length (Plate 1A). Over each eye single cirrus is observed, and a blackish-brown blotch on the dorsal side of the smooth skin is observed (Plate $1 \mathrm{~A})$.

2-Octopus vulgaris: The body is oval and small compared to the head and arms, covered with flattened tubercles. The head is large, with prominent eyes; three cirri are placed over each eye. The arms are thick and are seemingly equal in length, on their inner surface the suckers are seen, arranged in double rows (Plate 1B), and the bases of the arms are strongly webbed together. The dorsal pair of arms is shorter than the other arms, and the length of the arms is about three times the body length (Plate 1B).

3-Callistoctopus macropus: The dorsal body is ornamented with white spots. The arms are very long; 6-7 times longer than the body length. Each has two rows of suckers; the first pair of arms I is much longer than the rest (Plate 1C). The cirri over eyes are absent. 
4-Macrotritopus defilippi: The mantle is relatively very small, smooth-skinned, head narrower than the mantle, no pigmented ocellus, spots, or rings. Funnel elongate tube is observed. All arms are very long, slender, and symmetrical; the 3rd arms are very much longer than the other arms. Arm length exceeds $70-85 \%$ of the total length, arms with delicate (plate1D).

.Arms formula is as follows: III > II >IV > I or III > IV > II > I] (plate1D).

\section{II-Right arm III of male hectocotylized (PLATES 2 \& 3).}

1-Eledone moschata: The length of the right arm III hectocotylized is about $65 \%$ of the normal arms and the ligula occupies about $3 \%$ of the arm length (Plates 2A\&3A). Calimus is absent. The tips of the male normal arms are divided into two rows of flattish laminae 45 to 60 pairs, (Plates 2A\&3A)

2-Octopus vulgaris: The modified part of the right arm III of male hectocotylized is very small and spoon-shaped; the ligula occupies about $2.25 \%$ of its length (Plates $2 \mathrm{~B} \& 3 \mathrm{~B}$ ).

3-Callistoctopuss macropus: Right-arm III of male hectocotylized with a large tubular ligula, extending to about 13-15\% of its length (ligula index), (Plates 2C\&3C).

4-Macrotritopus defilippi: Right-arm III of male hectocotylized is shorter than the opposite arm bearing 60-100 suckers. Ligula is well differentiated about 1.8 to $2.5 \%$ of hectocotylized arm length, groove is very shallow (plates 2D\&3D).

\section{III- The Gills: (PLATES 4\&5)}

1-Eledone moschata: the gill is provided with eleven-gill lamellae (Plates 4A\&5A).

2-Octopus vulgaris: the gill is provided with eleven- gill lamellae (Plates 4B\&5B).

3-Callisoctopus macropus: the gill is provided with 13-gill lamellae (Plates 4C\&5C).

4-Macrotritopus defilippi: the gill is provided with 8-11 gill lamellae on the outer demi branch (Plates 4D\&5D).

IV-Radula :( PLATES 6 \& 7)

1-Eledone moschata: (Plates 6A\&7A).

2-Octopus vulgaris: (Plates 6B\&7B).

3-Callistoctopus macropus: (Plates 6C\&7C).

4-Macrotritopus defilippi: (Plates 6D\&7D).

V- The egg cluster :( PLATES 8 \& 9)

1-Eledone moschata: (Plates 8A\&9A).

2-Octopus vulgaris: (Plates 8B\&9B).

3-Callistoctopus macropus: (Plates 8C\&9C).

4-Macrotritopus defilippi: (Plates 8D\&9D).

The Beaks :( PLATES 10\& 11) 
1-Eledone moschata:(Plates 10A\&11A).

2-Octopus vulgaris: (Plates 10B \&11B).

3-Callistoctopus macropus: (Plates 10C\&11C).

4-Macrotritopus defilippi: (Plates 10D \&11D).
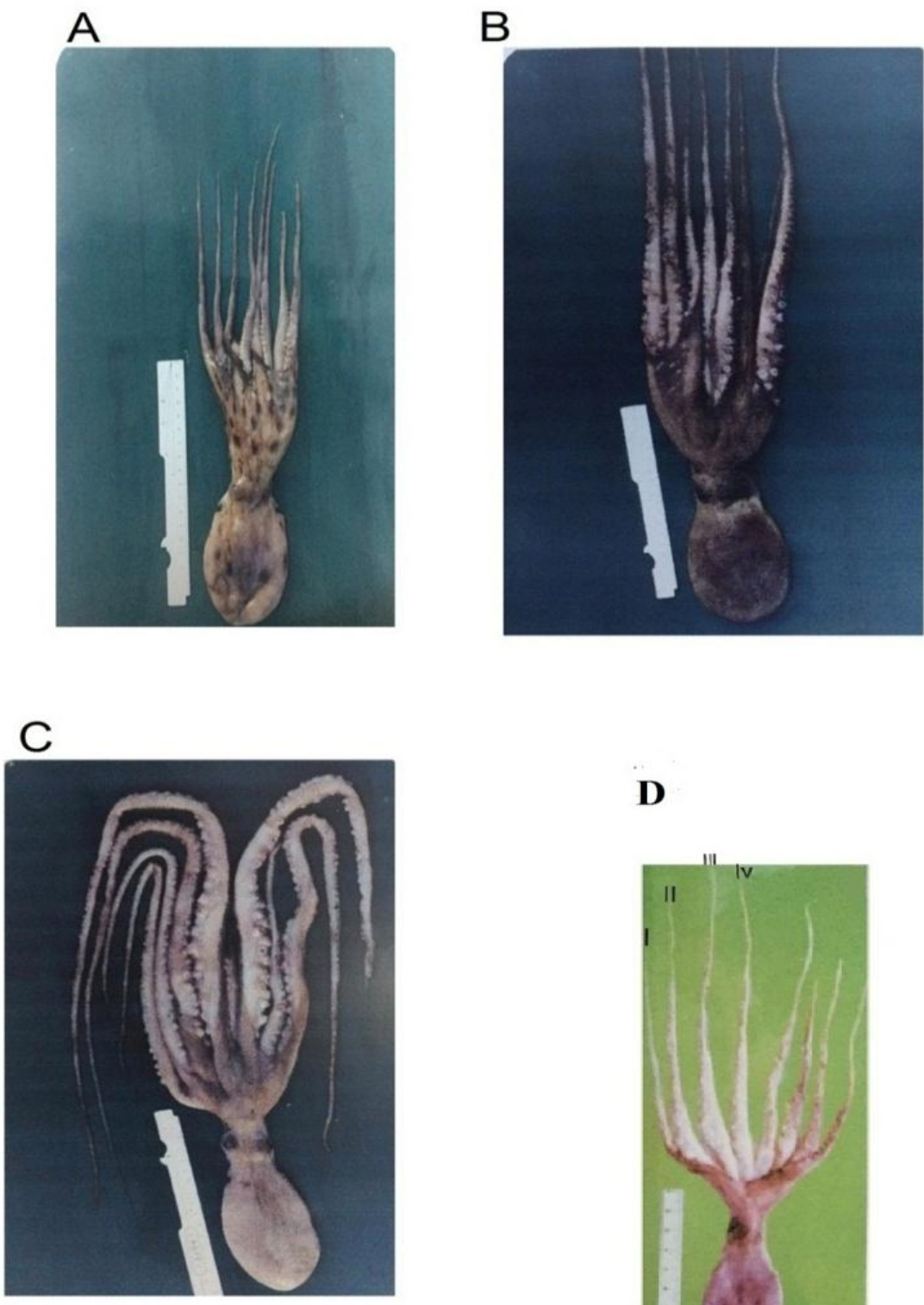

D

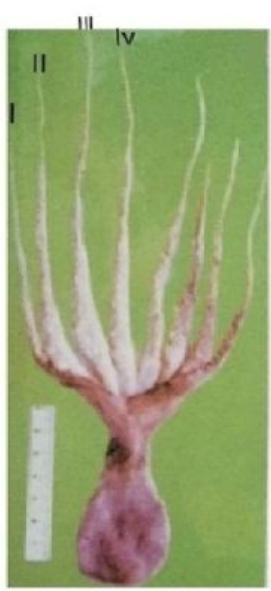

Arms formula $[\mathrm{III}>$ II $>$ IV $>$ I $]$ OR $[\mathbf{I I}>\mathbf{I V}>\mathbf{I I}>\mathbf{I}]$

PLATE (1): External morphological features

The specimens were photographed by a CanonG7X digital camera.
(A) Eledone moschata.
(B)Octopus vulgaris
(C) Callistoctopus macropus.
(D) Macrotritopus defilippi. 
A

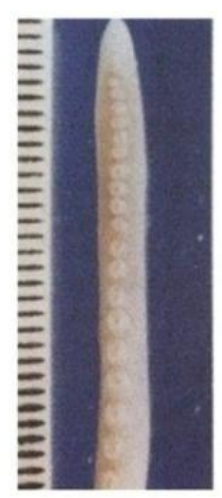

B

C

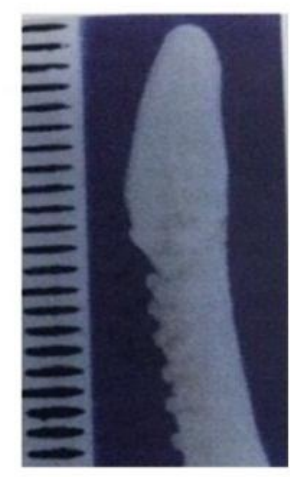

D

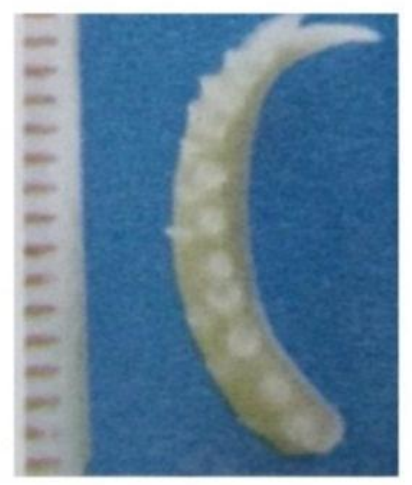

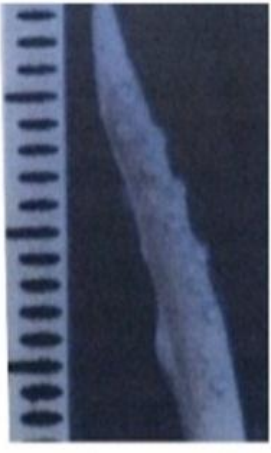

E

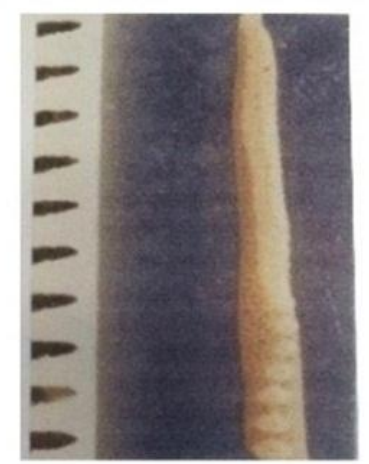

PLATE (2): Right arm III of male hectocotylized

The organs were photographed by a Canon G7Xdigital camera.
(A) Eledone moschata.
(B) Octopus vulgaris.
(C) Callistoctopus macropus
(D) Macrotritopus
defilippi
(E) Eledone moschata. (Male normal arm). 
A

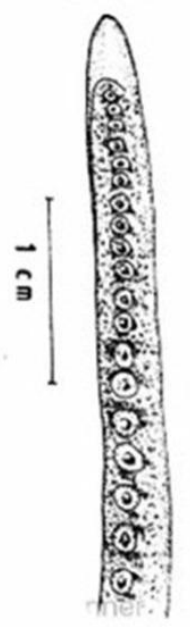

C

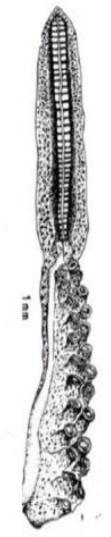

B

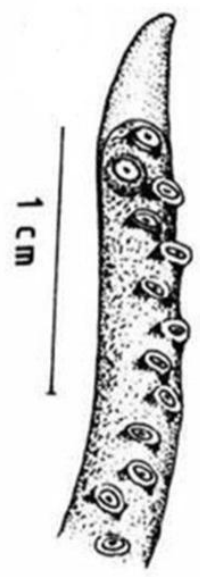

$E$

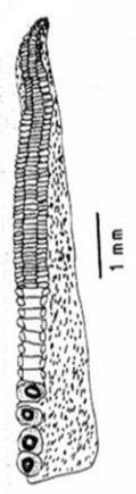

PLATE (3): Right arm III of male hectocotylized

The organs were illustrated using a zoom stereoscopic WildM8 microscope provided with its special Camera Lucida drawing tube.
(A) Eledone moschata.
(B) Octopus vulgaris.

(CCallistoctopus macropus

(D) Macrotritopus defilippi

(E) Eledone moschata (Male normal arm). 
A

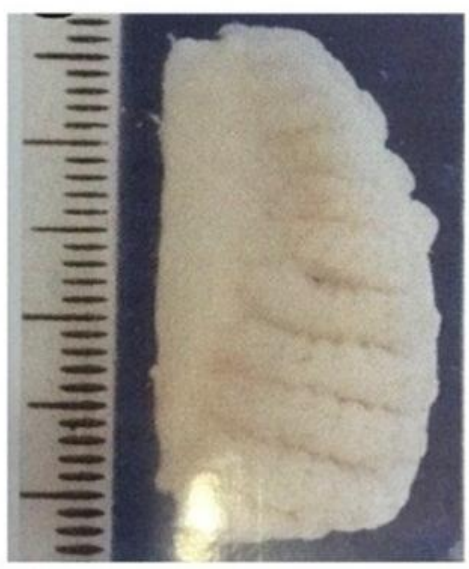

C

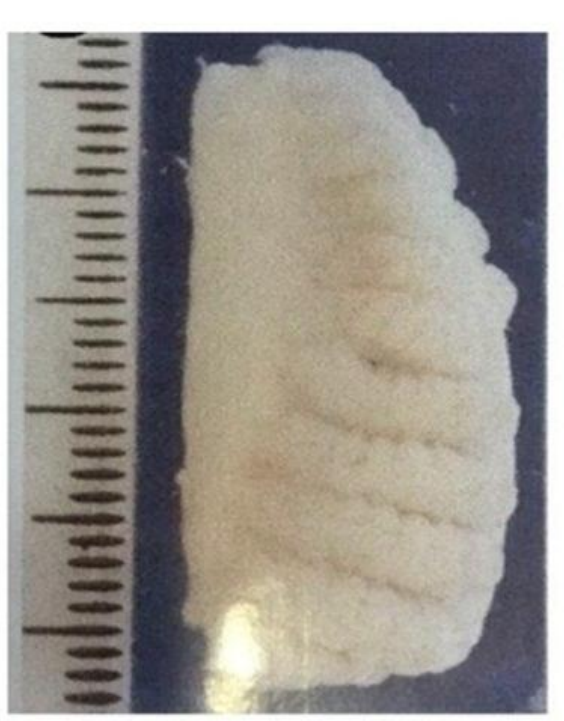

B

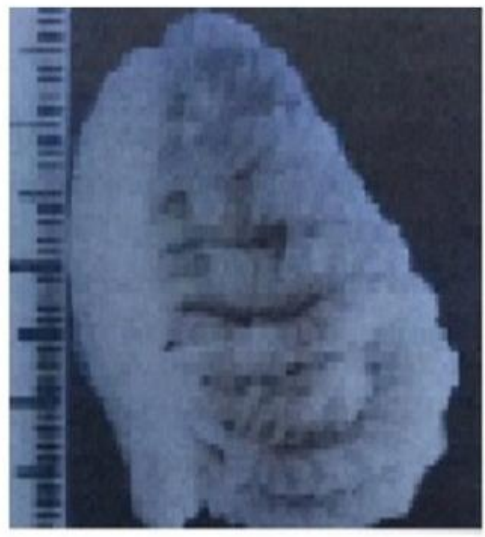

$\mathrm{D}$

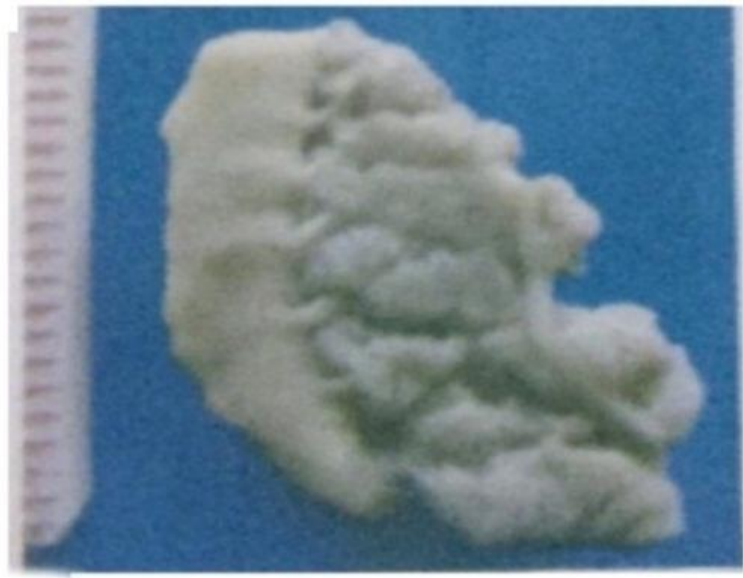

PLATE (4): Gills.

The organs were photographed by a Canon G7Xdigital camera.
(A) Eledone moschata.
(B) Octopus vulgaris

(CCallistoctopus macropus

(D Macrotritopus defilippi 

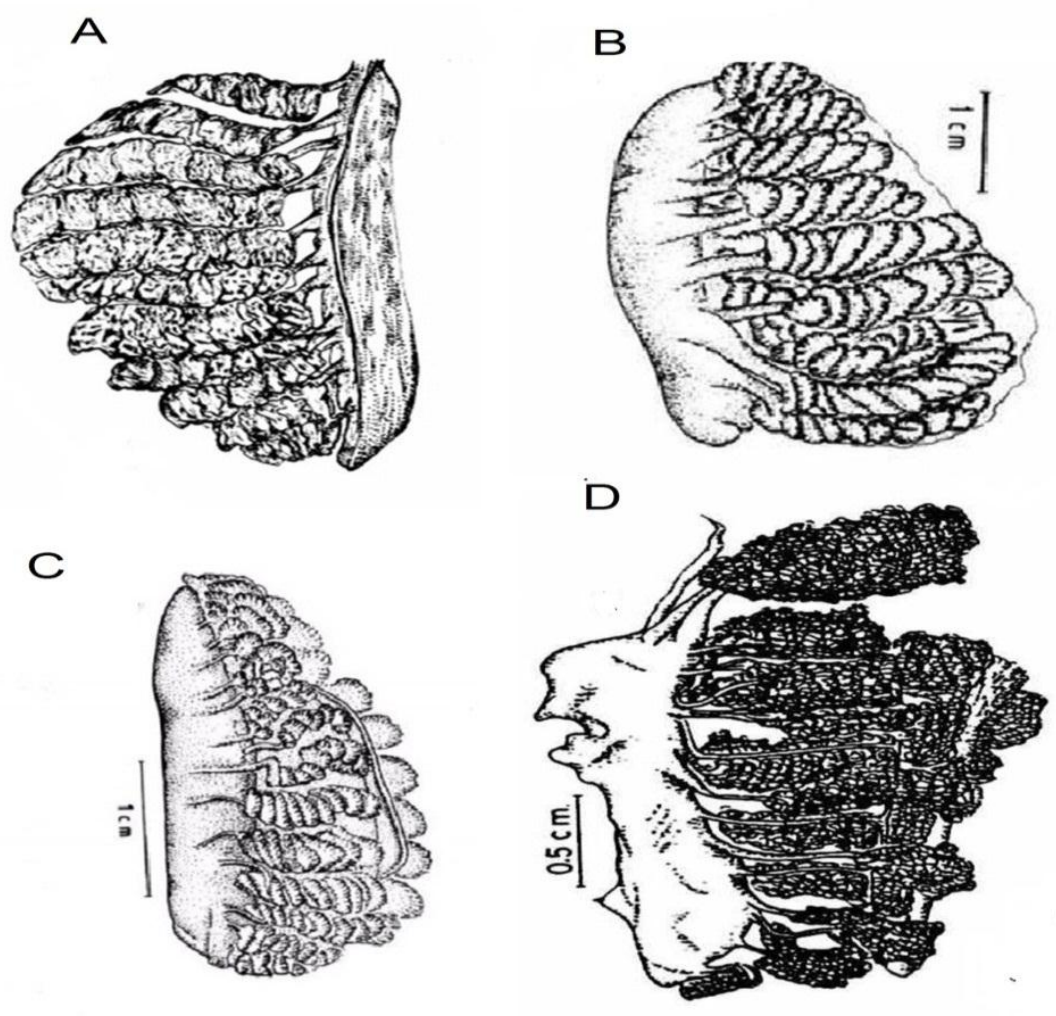

PLATE (5): Gills.

The organs were illustrated using a zoom stereoscopic WildM8 microscope provided with its special Camera Lucida drawing tube.
(A) Eledone moschata.
(B) Octopus vulgaris
(CCallistoctopus macropus
(D) Macrotritopus defilippi 

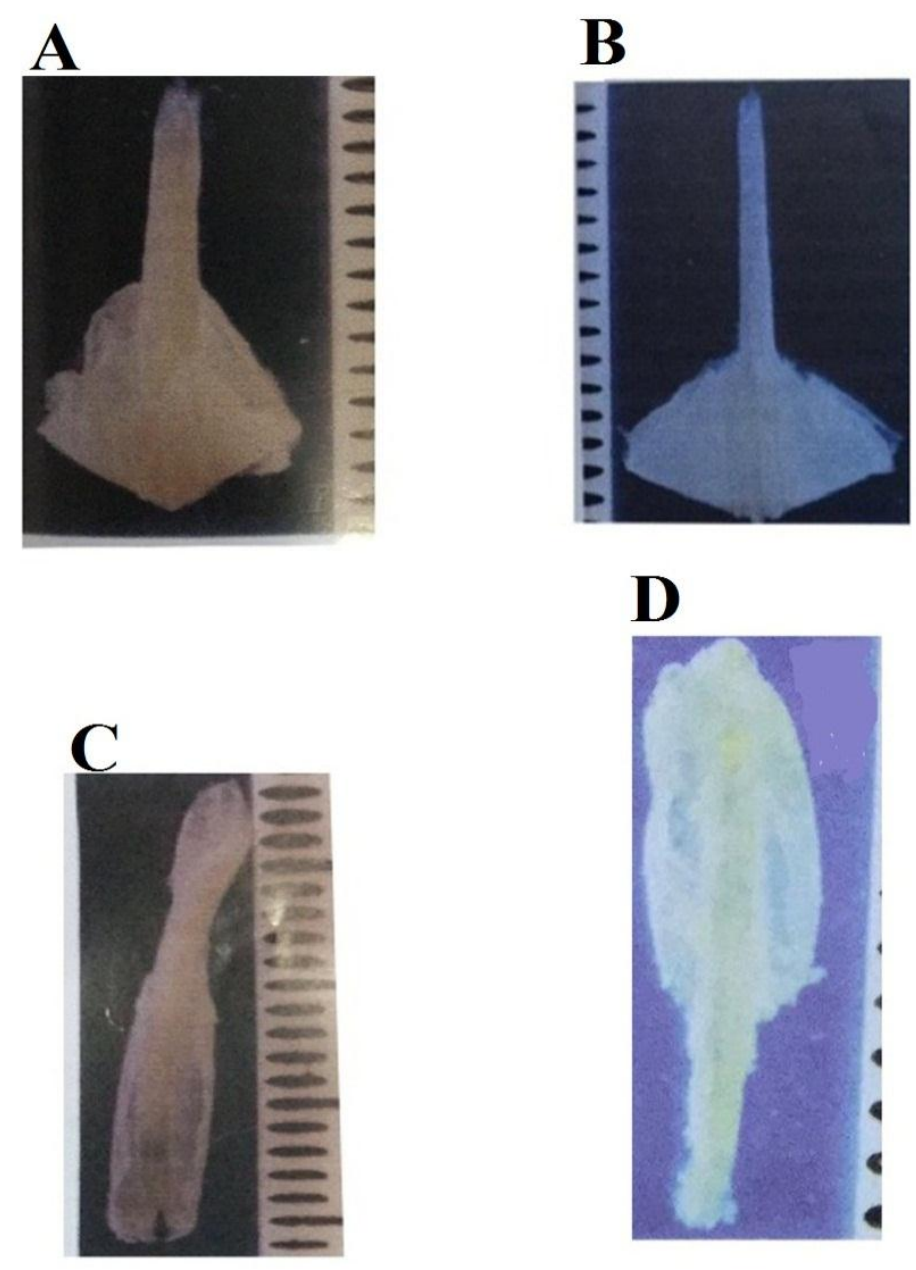

PLATE (6): Radula.

The organs were photographed by a CanonG7X digital camera.
(A) Eledone moschata.
(B) Octopus vulgaris
(CCallistoctopus macropus
(D) Macrotritopus defilippi 
A
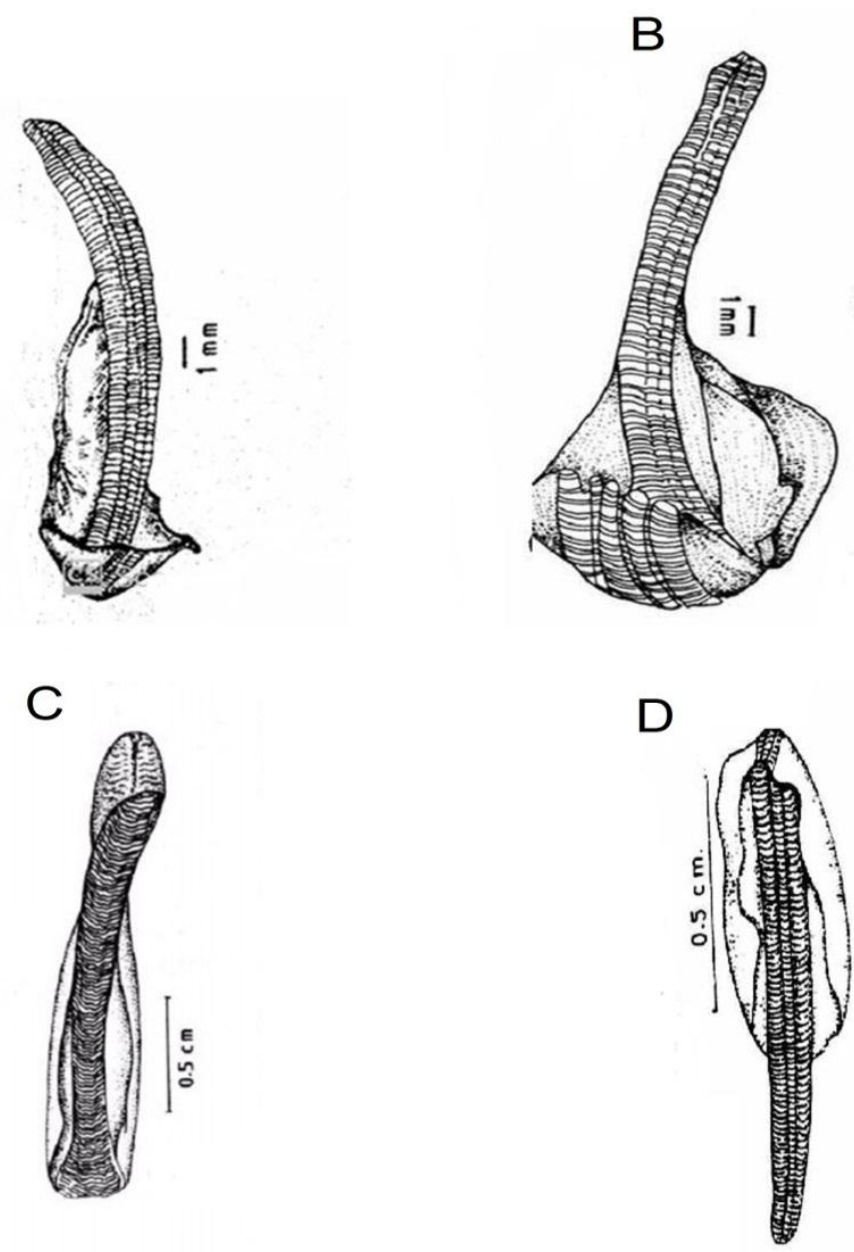

\section{PLATE (7): Radula}

The organs were illustrated using a zoom stereoscopic WildM8 microscope provided with its special camera Lucida drawing tube.
(A) Eledone moschata.
(B) Octopus vulgaris
(CCallistoctopus macropus
(D) Macrotritopus defilippi 


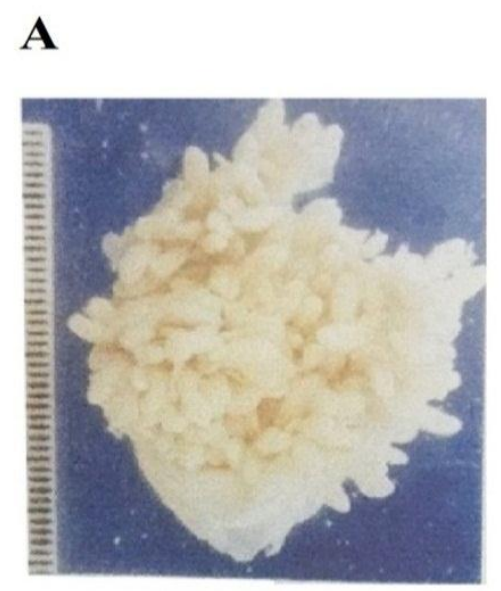

B

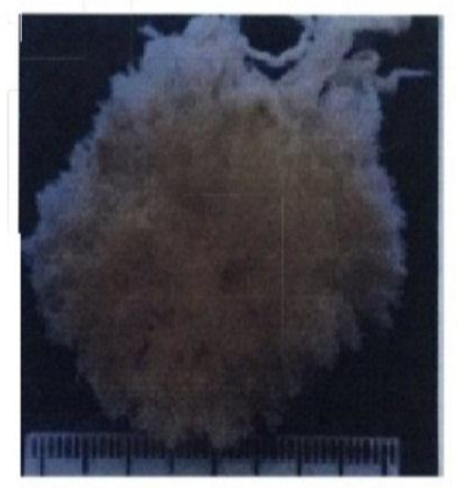

D
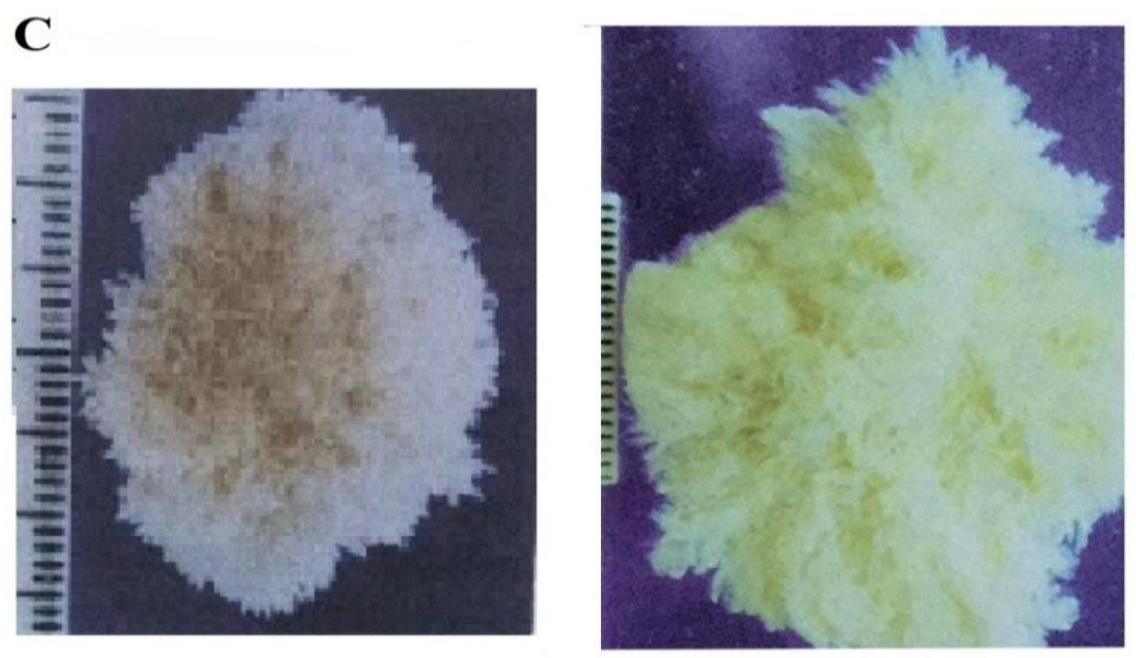

PLATE (8): Egg cluster.

The organs were photographed by a CanonG7X digital camera.
(A) Eledone moschata.
(B) Octopus vulgaris
(CCallistoctopus macropus
(D) Macrotritopus defilippi 
A

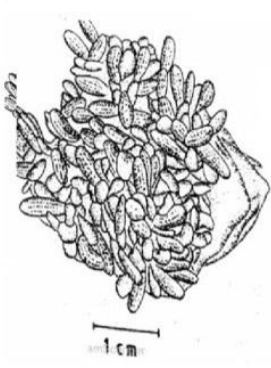

C

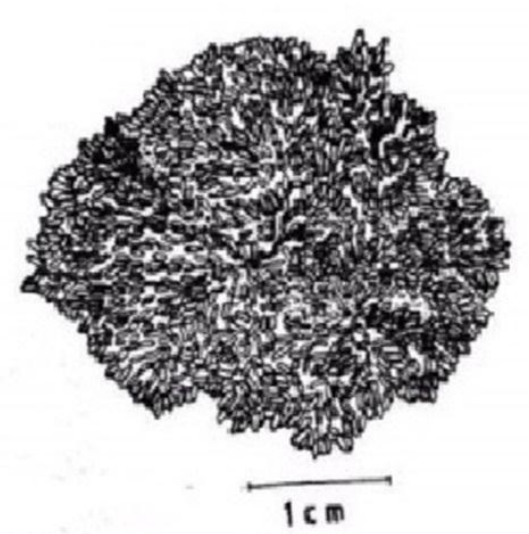

B

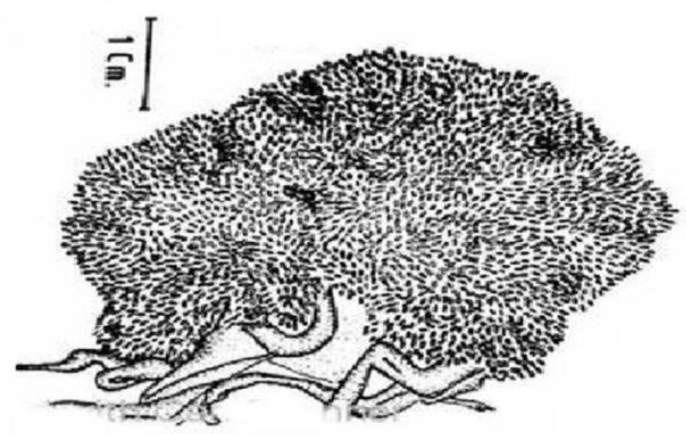

D

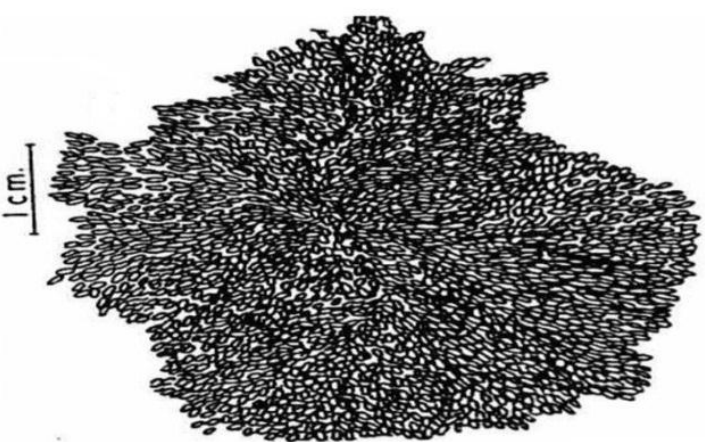

PLATE (9): Egg cluster.

The organs were illustrated using a zoom stereoscopic WildM8 microscope provided with its special camera Lucida drawing tube.
(A) Eledone moschata.
(B) Octopus vulgaris

(CCallistoctopus macropus

(D) Macrotritopus defilippi 


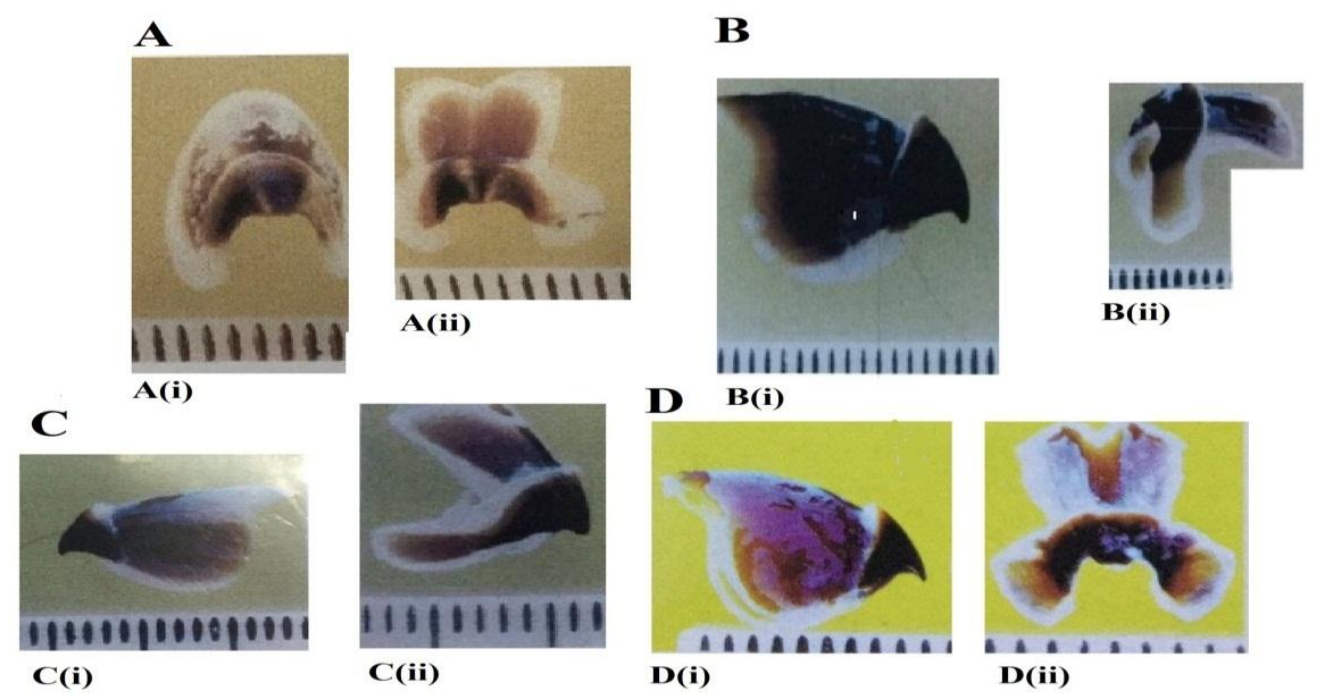

PLATE (10): Beaks.

The organs were photographed by a CanonG7X digital camera.
(A) Eledone moschata.
(B) Octopus vulgaris

(Ai) upper beak. (Aii) lower beak

(Bi) beak. (Bii) lower beak.

(C) Callistoctopus macropus

(D) Macrotritopus defilippi

(Ci) upper beak. (Cii) lower beak.

(Di) upper beak. (Dii) lower beak. 


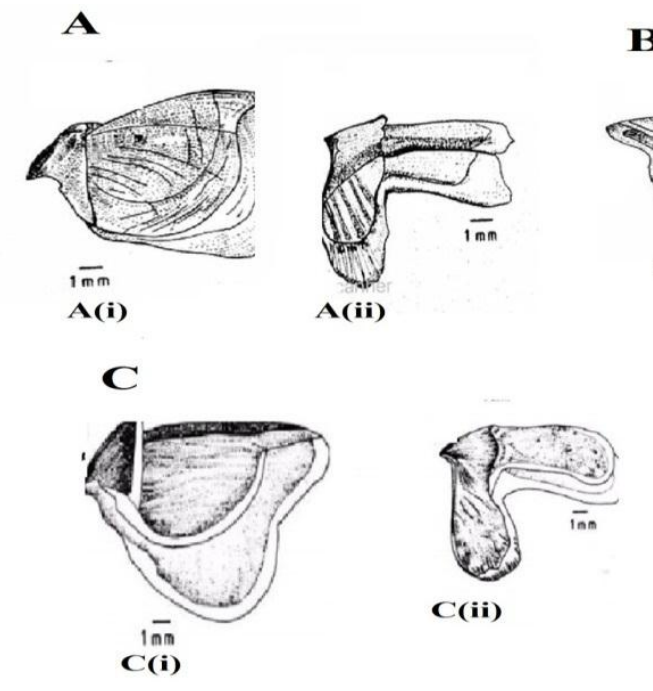

B

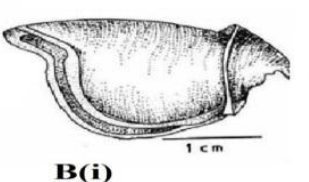

B(i)

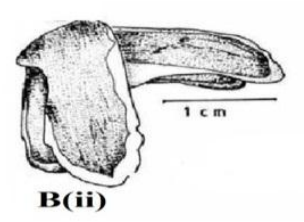

D
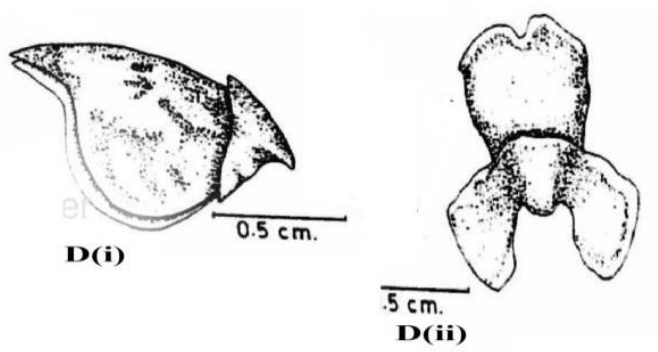

PLATE (11): Beaks.

The organs were illustrated using a zoom stereoscopic WildM8 microscope provided with its special camera Lucida drawing tube.
(A) Eledone moschata.
(B) Octopus vulgaris

(Ai) upper beak. (Aii) lower beak

(Bi) upper beak. (Bii) lower beak.

(C) Callistoctopus macropus

(D Macrotritopus defilippi

(Ci) upper beak. (Cii) lower beak.

(Di) upper beak. (Dii) lower beak. 


\section{REMARKS:}

1- The following four octopus species namely: Eledone moschata, Octopus vulgaris, Callistoctopus macropus, and Macrotitopus defilippi were encountered during the present study, three of them: Octopus vulgaris, Callistoctopus macropus, and Macrotitopus defilippi are cosmopolitan species in distribution. On the other hand, the species Eledone moschata are widely distributed in the Mediterranean Sea.

2- Eledone moschata: The morphology of Eledone moschata from the Egyptian Mediterranean waters is in agreement with the literature, except for the number of flattish laminae of the male normal arm which has not been reported before in the literature.

Considering the collected specimens, the largest specimens had a mantle length of 12.6 $\mathrm{cm}$ in male and $11.2 \mathrm{~cm}$ in female, with a total length of $59.5 \mathrm{~cm}$ for male and $51.2 \mathrm{~cm}$ for female and total weight of $566 \mathrm{~g}$ for male and $364 \mathrm{~g}$ for female. Fischer, (1973) measurement for total length is in the same recorded range $(50-60 \mathrm{~cm})$. The mantle length and total length of the present specimens are smaller than those given by Roper $\boldsymbol{e t}$ al. (1984) while the total length is remarkably bigger $(35 \mathrm{~cm})$ in the present study. The minimum-sized specimens showed a mantle length of $4.6 \mathrm{~cm}$ for male and $4.4 \mathrm{~cm}$ for female, a total length of $18 \mathrm{~cm}$ was observed for both sexes, and the total weight of $37 \mathrm{~g}$ was recorded for male and $25 \mathrm{~g}$ for female.

3-Octopus vulgaris: Octopus vulgaris is differentiated from Callistoctopus macropus by its shorter arms, the possession of a well-developed interbranchial membrane (connecting the arms up to $1 / 5$ of their length), and the presence of three cirri over each eye. On the other hand, Eledone moschata differs from Octopus vulgaris by having a single row of suckers on the arms and by the presence of single cirrus over each eye. The morphology of Octopus vulgaris in the present work is in agreement with the literature, except for the three cirri over each eye; this character was only stated by Forbes and Hanley (1852).

Of the specimens collected, the largest specimen had a total length of $104 \mathrm{~cm}$ for males and $99.6 \mathrm{~cm}$ for female. Fischer (1973) gave a maximum total length of 90 to $110 \mathrm{~cm}$. Moreover, Roper et al. (1984) reported much larger sizes, with a total length of $130 \mathrm{~cm}$ for male and $120 \mathrm{~cm}$ for female.

4-Callistoctopus macropus: Octopus macropus differs from Octopus vulgaris by some characters as: its slender and longer arms and its poorly developed interbranchial membrane. Eledone moschata differs from Callistoctopus macropus by its single row of suckers on the arms and its single cirrus over each eye, while cirri are absent in Callistoctopus macropus. The morphology of Callistoctopus macropus in the present study is in agreement with that given in the literature. The largest specimen had a mantle length of $16.2 \mathrm{~cm}$ for male and $15.8 \mathrm{~cm}$ for female, with a total length of $137 \mathrm{~cm}$ for male and $130 \mathrm{~cm}$ for female, and a total weight of $880 \mathrm{~g}$ for male and $625 \mathrm{~g}$ for female. The maximal total length recorded for the same species by Fischer (1973) ranged from 90 to 
$110 \mathrm{~cm}$. Roper et al. (1984) recorded greater measurements, total length $120-150 \mathrm{~cm}$, mantle length $14 \mathrm{~cm}$ and total weight of $2 \mathrm{~kg}$. The smallest specimen collected during this study showed the following measurements: a total length of $55 \mathrm{~cm}$ for male and $52 \mathrm{~cm}$ for female mantle length.

5-Macrotitopus defilippi: It is worth noting that Riad (2000b) detected Macrotitopus defilippi in the Egyptian Mediterranean waters as well as in the Egyptian Red Sea waters (Riad, 2008).

\section{REFERANCES}

Adam, W. (1960). Cephalopoda from the Gulf of Aqaba. Bull. Sea. Fish .Res.Stn .Haifa. 26: $1-27$.

Akimushkin, I.I. (1963). Cephalopods of the Seas of the USSR 235 page. Moscow: Academy of Science of the USSR, Institute of Oceanology. [In Russian]. English translation. 1965, 223 pages. Jerusalem: [Israel program for Scientific Translations].

Anonymous (1986-1998). Yearbook of fisheries statistics. National Institute of Oceanography and Fisheries, Alexandria, A.R.E. (In Arabic).

Byles, R.H.; McGuire W.and Sanders, M. F. (1979). Methods of isoelectric focusing. Am. J. Phys. Anthrop. 50: 27-34.

Clarke, M. R. (1962).The identification of cephalopod "beaks" and the relationship between beak size and total body weight. Bulletin British Museum History Zoology, 8:449-480.

Emam, W. M.; Ibrahim, A. M. and Ghareb, T. (2008). Macro and microscopic structure of the digestive system of Octopus vulgaris from Alexandria water on the Mediterranean Sea. J. Egypt. Acad. Soc. Environ. Develop., (D- Environmental Studies), 9 (2): 141-154.

Fischer,E. (1973). FAO species identification sheets for fisheries purp, Mediterranean and Black Sea (Fishing area37). Rom FAO. Vol.2.

Forbes, E. and Hanley, S. (1852). Ahistory of the British Mollusca and their shells. Vol.4. London. pp.207-243.

Hochberg, F.G.; Nixon, M.andToll, R.B. (1992). Order Octopoda Leach, 1818. In M.J. Sweeney, C.F.E. Roper, K. Mangold, M.R.Clarke and SV. Boletzky, editors. "Larval" and juvenile cephalopods: A Manual for their identification. Smithsonian Contributions to Zoology 513: 213-271.

Ibrahim, A.M.; Emam, W.M.; Kenchington, E.and Ghareb,K. T. (2006). Molecular phylogeny of three octopodid species from the Mediterranean water, Egypt. Egypt. J. Aquat. Biol. and Fish., 10(4):163-179. 
Jereb,P.;Roper,C.F.E.;Norman,M.D.and Finn,J.K.(2014). Cephalopods of the world. An annotated and illustrated catalogue of cephalopods species known to date. FAO Species Catalogue for Fishery Purposes, 3(4): 382.

Katagan, T. and Kocatas, A. (1990). Note preliminaire sur les cephalopods, des Eaux Torques. Rapp. Comm. Int. Mer. Medit., 32, 1: 242.

Mangold, K. (1998). The Octopodinae from the Eastern Atlantic Ocean and the Mediterranean Sea. In (Systematic and Biogeography of Cephalopods Volume II) in Smithsonian Contributions to Zoology. 586: 521-528.

Mangold, K. and Fioroni, P. (1966). Morphologie et biometrie des mandibules de quelques Cephalopodes Mediterranean's. Vie milieu 17A: 1139-1196.

Massy, A.L. (1928). On the Cephalopoda of the Natal Museum. Ann. Natal Mus, Part 2, 6 (1): 89-96+ Plate.Bull. Nat. Inst. of Oceanogr. \& Fish. A.R.E. 26, 167- 182.

Nesis, K.N. (1987). Cephalopods of the world. Squid, cuttlefishes, octopuses, Neptune City, NJ: T.F.H. Publications Inc., Ltd, 351 pp.

Nessim, A.B. and Riad, R. (2003). Bioaccumulation of heavy metals in Octopus vulgaris from coastal waters of Alexandria (Eastern Mediterranean), Chemistry and Ecology 19 (4), 275-281.

Riad, R. (1993). Studies on cephalopod molluscs of the Mediterranean waters of Alexandria. M. Sc. Thesis, Ocean. Dept., Fac. Sci., Alex. Univ., 246 pp. Institute of Oceanography and Fisheries, Alexandria. 167 pp.

Riad, R. (2000a).Biological and taxonomical studies on octopuses (Octopoda: Cephalopoda) from the Egyptian Mediterranean waters.Ph. D. Thesis, Faculty of Science, Alexandria University, Egypt, 236 pp.

Riad, R. (2000b) First record of Rossia macrosoma and Octopus defilippi (Cephalopoda: Mollusca) in the Egyptian Mediterranean waters.

Riad, R. (2008) Morphological and taxonomical studies on some cephalopods from the Suez Gulf and Red Sea.

Egypt. J. Aquatic. Research 34 (1), 176- 201.

Riad, R. and Gabr, H.R. (2007).Comparative study on Octopus vulgaris (Cuvier, 1797) from the Mediterranean and Red Sea coasts of Egypt.

Riad, R. and Kilada, R. (2012) Reproductive biology of the musky octopus Eledone moschata (Cephalopoda: Octopodidae) in the Eastern Mediterranean, Egypt

Riad,R. and Kilada, R. (2012). Egypt. J. Aquat. Biol and Fish 16 (4), 1 - 113. 
Riad, R.; Wadie, W.F. and Halim, Y. (1997). Development of Octopus vulgaris, Lamark from Egyptian Mediterranean waters. Bull. Nat. Inst.of Oceanogr. \& Fish. A.R.E. 23: 389-411.

Riedle, R. (1970). Fauna und flora der Adria. 463 - 469.

Robson, G. C. (1912). The Biogeography and Numerical Taxonomy of the Oegopsida.

Robson, G. C. (1926).Report on the Mollusca ( Cephalopoda). Cambridge Expedition to the Suez Canal. 321-329.

Robson, G. C. (1929). A monograph of the recent Cephalopoda based on the collections of the British Museum (Natural History) Part I. Octopodinae, 236 pages. London: British Museum (Natural History). collections of the British Museum (Natural History) Part I. Octopodinae, 236 pages. London: British Museum (Natural History).

Robson, G. C. (1930). Cephalopoda, 1. Octopoda "Discovery" Rep. 2: 373-401 + 2 Plates.

Robson, G.C. (1932). A monograph of the recent Cephalopoda. Part 2. The Octopoda. (Excluding the Octopodinae): 359 pages. London British Museum (Natural History).

Roeleveld, M. A. (1975). A revision of Massy's checklist of South African Cephalopoda. Ann. S. Afr. Mus. 66(11): 233-255.

Roper, C.F.E.; Sweeny, M.J. and Nauen, C.E. (1984). Cephalopods of the world. FAO Fisheries Synopsis 3 (125): 51-52 .

Saad, A. H. A. and Emam, W. M. (1998). Studies on poisonous salivery glands of Octopus vulgaris from the Mediterranean Sea. Proc. Egypt, Acad. Sci., 48: 81-93.

Villanueva, R.; Sanchez, P. and Compagno Roeleveld, M. A. ( 1992). Octopus magnificus (Cephalopoda: octopodidae), a new species of large octopod from the southeastern Atlantic. Bulletin of Marine.

Voss, G. L. (1967). Some bathypelagic cephalopods from South African Waters. Annals of the South African Museum 50 (5): 61-88. 